\section{DIARY}

12th International Congress on Cleft Lip/Palate and Related Craniofacial Anomalies

Date: 5-10 May 2013 Location: Orlando, Florida www.cleft2013.org/program.html

Lingual training for orthodontic therapists and nurses

Date: 10 May 2013

Venue: BOS

12 Bridewell Place, London www.blos.co.uk/meetings.php

Occlusion in Everyday

Practice (BSOS)

Date: 10 May 2013

Location: Glasgow

Email:info@bsos.org.uk

Scottish Dental Show

Date: 16-17 May 2013

Venue: Hampden Park, Glasgow

www.scottishdentalshow.co.uk

Oral health care for children

Date: 21 June 2013

Venue: Leeds Marriott Hotel, Leeds www.bda.org/seminars

A Multi Disciplinary Approach to Dentofacial Orthopaedics

Date: 24 May 2013

Venue: Holiday Inn,

Welbeck Street, London

Telephone: Richard Dean,

01342824580

Premium education on digital dentistry: Sirona Imaging User Days

Date: 7 June 2013

Telephone: 08450715040

Email: info@sironadental.co.uk

British Society of Gerodontology and National Oral Health

Promotion Group Combined

Study Day 2013

Date: 14 June 2013

Venue: Burlington Macdonald Hotel,

Birmingham

www.nohpg.org

www.gerodontology.com

Armed Forces Study Day

Date: 4 July 2013

Venue: BDA HO, London

Email: fraser.sneddon582@mod.uk

Association for Dental Education

in Europe meeting

Date: 28-31 August 2013

Venue: Wolfson Centre

University of Birmingham

www.birmingham.ac.uk/adee2013

\title{
TAKING THE PAIN OUT OF MILTON KEYNES
}

Drill-less, needle-free and painless dental treatment in a relaxing and comfortable setting has 'arrived' in Milton Keynes with the opening of Dentist Direct in Grange Farm.

\section{Dentist Direct Milton}

Keynes opened its doors on 27 March, offering Waterlase technology, a combination of YSGG laser energy and water (HydroPhotonics), which is used to perform many traditional dental procedures with less anaesthesia. It is designed to reduce patient anxiety, minimise pain and trauma and create a more comfortable experience for patients.

\section{SURPLUS SUPPLIES NEEDED FOR ZANZIBAR}

Retired Brighton-based dentist Dr Feroz Jafferji is appealing for any redundant/useful dental items for a project aiming to create at least two new fullyfunctioning dental clinics in Zanzibar, 'The Spice Island' $40 \mathrm{~km}$ off the coast of Tanzania.

Dr Jafferji is originally from Zanzibar and after returning to the country three years ago he linked up with former classmates and formed 0Z: Outreach Zanzibar. OZ has joined forces with Health Improvement Project, Zanzibar (HIP Z), a British charity set up by medical professionals in collaboration with Zanzibar's Ministry of Health, helping to raise awareness of the lack of medical facilities and extremely low life expectancy on the island.

To find out more visit http:// outreachzanzibar.org; if you are able to donate any small or large equipment, hand instruments or consumables email fjafferji@outreachzanzibar.org.
The practice's principal dentist is Mrs Girija Sree Challa (pictured, right, with Craig Huntingdon, Dentist Direct's CEO), who also has a master's degree in children's dental health. 'Our treatments ensure comfort and accuracy and reduce bleeding, post-treatment pain and swelling, said Mrs Challa, 'which is very important for children, but great for adults too!'

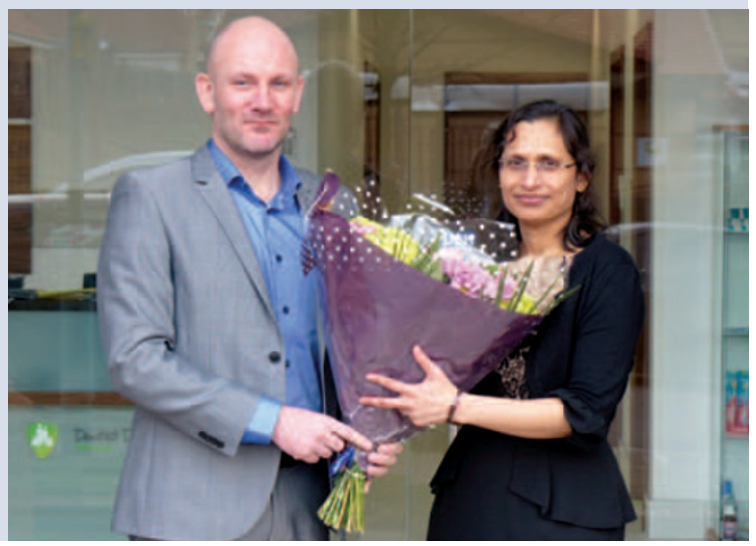

\section{DENTAL NURSE BOOM IN SCOTLAND}

There has been an increase of over 65\% in numbers of NHS dental nurses in Scotland in the last five years, as reported on scotsman.com, from 862 in 2007 to 1,426 in 2012. The number of dental technicians has also risen over the same period from 48 to 130 .

\section{BECOME ACCREDITED IN MOUTH CANCER SCREENING \\ At this week's British \\ Dental Conference and

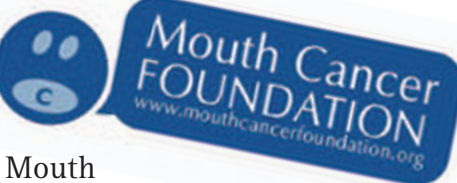

Exhibition at ExCeL London, Mouth

Cancer Foundation Ambassador Dr Philip Lewis was due to explain to delegates how by carrying out thorough head and neck cancer checks at routine appointments, lives will be saved.

The presentation was the formal launch of the Mouth Cancer Foundation's new screening initiative, the Mouth Cancer Screening Accreditation Scheme. The scheme will recognise dental practices that demonstrate a visible commitment to increasing public awareness of mouth cancer screening to all patients and establish a documented referral pathway with a local specialist department.

Dr Lewis said: 'The Mouth Cancer Screening Accreditation Scheme offers lots of benefits to practices. As well as saving lives it is a practice builder. It encourages footfall and trust. The scheme is as much about educating the public as it is about screening them.'

The scheme is open to any dental practice with GDCregistered clinicians. For more information email info@ mouthcancerfoundation.org or telephone 01924950950. 